\title{
Penerapan Model Latihan Small-Side Games terhadap Peningkatan Intrinsic Motivation dan Social Behavior Siswa
}

\section{Implementation of The Small-Side Games Exercise Model on Intrinsic Motivation Improvementand Social Behavior Students}

\author{
Yuga Rahmatullah Lugaya, Komarudin \& Mustika Fitri \\ Universitas Pendidikan Indonesia, Bandung, Jawa Barat, Indonesia \\ yugalugaya@gmail.com
}

Naskah diterima tanggal 18/05/2019, direvisi akhir tanggal 10/06/2019, disetujui tanggal 11/12/2019

\begin{abstract}
Abstrak
Tujuan dari penelitian ini adalah dapat menghasilkan metode pembelajaran yang dapat meningkatkan motivasi intrinsik dan perilaku sosial siswa dalam pembelajaran pendidikan jasmani. Adapun tujuan khusus dari penelitian ini adalah untuk mengetahui pengaruh model latihan small-side games terhadap peningkatan intrinsic motivation siswa dalam pembelajaran bolabasket, dan untuk mengetahui pengaruh model latihan small-side games terhadap peningkatan social behavior siswa dalam pembelajaran bolabasket. Hasil penelitian menunjukan bahwa model latihan small-side games yang disusun secara terstruktur dengan proses integrasi intrinsic motivation dan social behavior memiliki hasil dan pengaruh yang signifikan terhadap pengembangan dari keduanya. Selanjutnya, guru pendidikan jasmani dapat menggunakan program yang sengaja disusun tersesbut untuk pengembangan aspek afektif melalui berbagai aktivitas olahraga.
\end{abstract}

Kata kunci: Small-Side Games, Motivasi Intrinsik, Perilaku Sosial

\begin{abstract}
The aim of this study is to be able to produce learning methods that can increase intrinsic motivation and social behavior of students in physical education learning. The specific purpose of this study was to determine the effect of the small-side games training model on increasing intrinsic motivation of students in basketball learning, and to determine the effect of the smallside games training model on improving students'social behavior in basketball learning. The results showed that the small-side games training model that was structured in a structured manner with the integration process of intrinsic motivation and social behavior had results and had a significant effect on the development of both. Furthermore, physical education teachers can use programs that are deliberately arranged to develop affective aspects through various sports activities.
\end{abstract}

Keywords: Small-Side Games, Intrinsic Motivation, Social Behavior

\section{PENDAHULUAN}

Small-sided game (SSGs) digunakan dalam proses pengajaran-pembelajaran atau pelatihan olahraga tim, karena mereka menyajikan komponen taktis-teknis, fisik, dan lainnya yang terkait dengan kinerja permainan (Hoffmann et al., 2014). SSG juga menghadirkan karakteristik organisasi yang mirip dengan game formal (Davids et al.,
2013), dan kondisinya dapat dengan mudah dimodifikasi untuk melatih komponen game tertentu sambil mempertahankan logika game. Model pengajaran yang fokus pada pengetahuan taktis deklaratif / prosedural menggunakan SSG untuk memfasilitasi pemahaman pemain tentang permainan formal (Greco et al., 2010). Memodifikasi kondisi SSG (misalnya, jumlah pemain per 
tim) dapat mengubah karakteristik lingkungan dalam mode yang dapat dikendalikan dan dapat mendorong atlet/siswa untuk melakukan perilaku yang diinginkan (Arau jo, 2013; Davids et al., 2006). Oleh karena itu, perubahan sistematis dalam kondisi SSG memungkinkan guru dan pelatih untuk menyesuaikan tuntutan taktis-teknis sesuai dengan tujuan praktik / pelatihan mereka.

SSG dapat didefinisikan sebagai permainan terbatas yang dipraktikkan di ruang kecil, seringkali dengan aturan yang diadaptasi dan jumlah pemain yang lebih sedikit (Hill-Haas et al., 2011). Kendala ini memungkinkan mengadaptasi permainan dengan karakteristik dan kebutuhan pemain, yang menjadikan SSG kerangka kerja istimewa dalam pengajaran olahraga tim (Ortega, Alarcón dan Piñar, 2012; Owen, Twist dan Ford, 2004). Penurunan jumlah pemain memungkinkan setiap pemain untuk lebih sering melakukan kontak dengan bola, sehingga menghasilkan lebih banyak dribbling, passing, shooting dan steal (Koklu et al., 2011; Reilly, 2005), yang dapat berkontribusi pada pengembangan teknis yang lebih baik. Pengetahuan taktis para pemain dapat dikembangkan dengan terus-menerus mengekspos pemain ke situasi offensive dan deffensive (Dellal et al., 2011). Masalah taktis SSG ini membutuhkan kreativitas untuk diselesaikan. Kreativitas dapat didefinisikan sebagai kemampuan untuk membuat keputusan yang bervariasi, langkah dan fleksibel yang akan memungkinkan pemain untuk memecahkan masalah taktis yang muncul dalam kursus permainan dan yang sangat penting untuk olahraga tim (Memmert, 2010; Memmert \& Roth, 2007). Kemampuan pengambilan keputusan ini akan meningkat jika pelaku mempelajari cara menyelaraskan informasi lingkungan yang relevan yang mendukung tindakan yang sigap dan mengeksplorasi perilaku (Davids et al., 2013; Travassos et al., 2012).

Memotivasi siswa adalah salah satu tugas penting guru pendidikan jasmani (PE) yang harus dihadapi dalam kelas regular pendidikan jasmani. Guru olahraga harus menerapkan strategi atau cara memotivasi untuk melibatkan siswa yang tidak termotivasi dan juga mempertahankan motivasi pada siswa yang sudah terlibat. Guru pendidikan jasmani perlu mengetahui dasar-dasar ilmiah dan temuan penelitian di bidang motivasi siswa dalam pembelajaran penjas. Upaya penelitian yang menargetkan motivasi dalam pendekatan dibidang pendidikan jasmani hampir secara khusus dari pandangan psikologis sosial. Menurut (Lirgg, 1991), kontribusi terbesar dan paling signifikan dalam penelitian psikologi sosial terhadap pendidikan jasmani selama 30 tahun terakhir berkaitan dengan motivasi. SelfDetermination Theory (SDT) (Ryan \& Deci, 2000) telah menjadi kerangka teoritis yang paling banyak digunakan saat menyelidiki motivasi siswa dalam pendidikan jasmani (Ntoumanis \& Standage, 2009), karena SDT menyediakan kecocokan yang sangat baik untuk aktivitas fisik dan pengaturan pembelajaran pendidikan jasmani (Boiché et al., 2009)

Faktor-faktor yang memengaruhi motivasi siswa di PE dapat dibagi menjadi dua aspek yaitu internal dan eksternal. Faktor internal mengandung karakteristik individu (misalnya usia, jenis kelamin, tingkat kelas sekolah, tingkat kemampuan, ciri fisik), variabel karakter (misalnya sikap, kompetensi yang dirasakan, orientasi tugas dan ego, orientasi tujuan, motivasi intrinsik), dan variabel situasi individu (misalnya latihan olahraga selama waktu luang, alasan untuk mengikuti olahraga, persepsi tentang keberhasilan) (Blanchard et al., 2007; Cloes, 2005). Empat variabel karakter terkait dengan perbedaan individu telah terbukti mempengaruhi motivasi intrinsik pada pendidikan jasmani. Ini adalah kompetensi yang dirasakan, kemandirian yang dirasakan, menjelaskan tujuan pencapaian, dan manfaat yang dirasakan dari kelas pendidikan jasmani (Hassandra et al., 2003). Jika siswa merasa bahwa mereka bisa melakukan suatu hal dalam kelas pendidikan jasmani, mereka juga akan merasa senang untuk berpartisipasi aktif (Cairney et al., 2012; Kolovelonis \& Goudas, 2013). Siswa yang merasa bisa melakukan suatu tugas dengan sendiri di 
kelas pendidikan jasmani menunjukkan tingkat motivasi intrinsik yang lebih tinggi (Goudas et al., 1994; Hagger et al., 2005). Ada yang berpendapat bahwa motivasi intrinsik adalah keinginan bertindak yang disebabkan faktor pendorong dari dalam diri (internal) individu (Thornburgh, 2006). Individu yang digerakkan oleh motivasi intrinsik, baru akan puas kalau kegiatan yang dilakukan telah mencapai hasil yang terlibat dalam kegiatan itu. Sedangkan menurut (Gunarsa, 2008) motivasi intrinsik merupakan dorongan atau kehendak yang kuat yang berasal dari dalam diri seseorang. Semakin kuat motivasi intrinsik yang dimiliki oleh seseorang, semakin besar kemungkinan ia memperlihatkan tingkah laku yang kuat untuk mencapai tujuan.

Social Cognitive Theory (Bandura, 1999) dapat berfungsi sebagai kerangka kerja untuk memahami aktivitas fisik remaja selama pendidikan jasmani (Motl, 2007). Teori Kognitif Sosial menekankan bahwa tindakan dipengaruhi oleh faktor pribadi, lingkungan dan perilaku yang dinamis dan selalu berinteraksi (Bandura, 1999). Diterapkan pada pendidikan jasmani, teori kognitif sosial menunjukkan bahwa faktor lingkungan, seperti konteks kelas, isi pelajaran, dan perilaku guru, mempengaruhi perilaku murid secara langsung atau tidak langsung melalui perubahan yang menentukan dalam kepribadian seseorang (misalnya kesenangan, kemampuan seseorang). Berbagai intervensi pembelajaran keterampilan sosial sudah efektif dalam meningkatkan keterampilan sosial yang sesuai dalam lingkungan pendidikan. Pengajaran keterampilan sosial, berdasarkan teori belajar sosial (Bandura, 1977) adalah lebih menekankan hal yang positif untuk dapat menggantikan perilaku negatif dengan hal yang lebih baik dilakukan siswa dan untuk mengajar siswa lebih membangun perilaku sosial yang bermanfaat untuk kedepannya (Cartledge et al., 2008; Chen, 2006). Instruksi ini biasanya melibatkan contoh perilaku sosial, umpan balik, praktik langsung, penguatan, mencoba berperilaku, dan perubahan perilaku (Moore et al.,1995). Berdasarkan teori belajar sosial, sebagian besar perilaku dipelajari dan dengan demikian instruksi langsung dapat digunakan untuk mengajarkan perilaku sosial yang sesuai (Ormrod 1999).

Tujuan utama dalam mengembangkan orang yang berpendidikan fisik adalah untuk membantu siswa terlibat dalam perilaku sosial yang positif (NASPE, 2004). Sebagai contoh, akan lebih menguntungkan bagi siswa untuk terlibat dalam perilaku prososial lebih sering. Statistik yang terakhir ini sejalan dengan statistik nasional bahwa sekitar 41\% siswa diintimidasi setidaknya satu kali selama masa sekolah (Nansel et al., 2001). Oleh karena itu, beberapa tingkat perilaku intimidasi dan antisosial umum terjadi di antara siswa pendidikan jasmani sekolah menengah. Mengingat keinginan untuk memperkuat perilaku sosial yang positif dan mengurangi perilaku intimidasi dan dampak buruknya terhadap kesehatan mental (Kaltiala-Heino et al., 2000), ada baiknya untuk mengeksplorasi faktor-faktor yang dapat memprediksi perilaku sosial dalam pendidikan jasmani.

Dengan isi permainan dalam pembelajaran pendidikanjasmani, lingkungan yang kompetitif diketahui bermanfaat bagi para siswa yang sering mengalami kesuksesan (kemenangan) dan melihat kompetensi fisik mereka untuk menjadi sama atau lebih baik daripada teman yang lainnya, sedangkan kompetensi yang dirasakan dan motivasi intrinsik akan menurun untuk siswa yang mengalami hasil yang kurang menguntungkan, dibandingkan dengan teman-teman yang lainnya (yaitu kekalahan) (Vallerand et al., 1986); oleh karena itu, salah satu faktor kunci pada anak perempuan yang tidak menyukai pembelajaran pendidikan jasmani dan memiliki tingkat kompetensi yang lebih rendah selama pembelajaran pendidikan jasmani adalah partisipasi wajib dalam persaingan, yang umumnya tidak disukai oleh perempuan (Corbin, 2002; Reinboth, Michael; Duda, Joan; Ntoumanis, 2004). Malone \& Lepper (1987) mengklaim bahwa setiap individu menginginkan tingkat tantangan yang optimal; artinya, kita ditantang oleh aktivitas yang tidak 
terlalu mudah dan tidak terlalu susah untuk dilakukan. Selain itu, ada beberapa cara di mana tingkat tantangan yang optimal dapat diperoleh. Tujuan harus ditetapkan secara jelas, namun kemungkinan untuk mencapai suatu tujuan itu harus tidak pasti. Permainan harus menggunakan tingkat kesulitan progresif, banyak tujuan, dan ambiguitas informasi untuk memastikan hasil yang tidak pasti. Umpan balik kinerja dan pencatatan skor memungkinkan individu untuk melacak kemajuan menuju tujuan yang diinginkan. Akhir dari tujuannya harus berarti bagi individu. Menghubungkan kegiatan dengan kompetensi pribadi yang berharga, menanamkan kegiatan dalam menerima instruksi yang menarik, atau melibatkan motivasi kompetitif atau kooperatif dapat berfungsi untuk membuat tujuan bermakna. Selain itu, kompetensi yang dirasakan siswa sekolah menengah pertama khususnya perempuan ditemukan sangat rendah selama kegiatan kompetitif di kelas, dan terutama terlihat selama permainan invasi di Phisycal Education (yaitu sepak bola, bola basket, bola tangan, dan yang lainnya). Mentransformasi permainan invasi ke dalam bentuk permainan yang dimodifikasi dengan aturan yang disederhanakan (misalnya, tidak ada giring yang diizinkan dan grup yang lebih kecil) dapat berkontribusi pada keyakinan selfefficacy perempuan dan posisi yang lebih setara dengan anak laki-laki di kelas co-educational.

Maka dari itu tujuan utama dari penelitian ini adalah untuk mengetahui pengaruh small-side games terhadap motivasi intrinsik dan perilaku sosial dalam pembelajaran pendidikan jasmani dari sekelompok murid sekolah menengah pertama (usia 12-14 tahun). Tujuan kedua dari penelitian ini adalah untuk menyelidiki adakah perbedaan motivasi intrinsik dan perilaku sosial antara kedua kelas yang salah satunya diberikan penerapan model latihan small-side games.

\section{METODE PENELITIAN}

\subsection{Partisipan dan Prosedur Penelitian}

Selama dua dekade terakhir, telah diklaim bahwa tingkat aktivitas fisik (Physical Activity) telah menurun dan sejumlah besar remaja, terutama perempuan, tidak cukup aktif (Biddle et al., 2004; Sallis et al., 2000). Maka dari itu peneliti akan melakukan program modifikasi pembelajaran kepada anak usia remaja awal (12-15 Tahun), di sekolah menengah pertama. Sampel dalam penelitian ini dipilih secara random tanpa mengubah kelas yang ada. Populasi yang berjumlah 48 siswa dirandom dengan cluster random sampling. Sampel penelitian diseleksi berdasarkan kelompok atau kelas yang berjumlah 2 kelas. Freankel. Et. al. (2012, hlm. 175) "cluster sampling is used when it is more feasible to slect groups of individual rather than individuals from a defined population." Pada penelitian ini pembagian kelompok ditentukan berdasarkan tingkatan kelas, dengan treatment penerapan model latihan Small-Side Games adalah kelompok kelas VII (tujuh), sedangkan kelompok kedua dengan treatment penerapan model konvensional adalah kelas VIII (delapan). Sampel yang terpilih merupakan siswa kelas VII dan VIII SMPN 1 Subang yang sedang mengikuti ekstrakulikuler bolabasket di sekolah. Sampel yang terpilih benar-benar siswa yang hanya mengikuti satu kegiatan ekstrakulikuler bolabasket.

Peneliti menggunakan percobaan ketika ingin menetapkan sebab dan akibat yang mungkin antara variabel independen dan dependen. Ini berarti bahwa peneliti mencoba untuk mengontrol semua variabel yang mempengaruhi hasil dari variabel independen. Bahan penting dari desain eksperimental yang benar adalah bahwa subjek secara acak ditugaskan ke kelompok perlakuan. Pemberian tugas acak adalah teknik yang kuat untuk mengendalikan beberapa karakteristik subjek terhadap validitas internal, pertimbangan utama yang digunakan dalam penelitian pendidikan. Dua kelompok subjek digunakan/ ditentukan, lalu kedua kelompok diukur atau diamati sebanyak dua kali tes. Pengukuran pertama disebut sebagai pretest, dan yang kedua sebagai positest.

\section{Tabel 1. Desain Penelitian}

\begin{tabular}{|c|c|c|c|c|}
\hline \multicolumn{5}{|c|}{$\begin{array}{l}\text { The Randomized Pretest-Posttest } \\
\text { Control Group Design }\end{array}$} \\
\hline Treatment group & $\underline{R}$ & $O$ & $X$ & $O$ \\
\hline Control group & $R$ & $O$ & $C$ & $O$ \\
\hline
\end{tabular}


Saat mengumpulkan data untuk studi, ada beberapa langkah yang harus dilakukan peneliti, seperti memilih peserta, mendapatkan izin, memilih jenis data, mengidentifikasi instrumen, dan mengelola pengumpulan data. Setelah peneliti mengetahui apa yang harus dilakukan pada saat penelitian berlangsung, maka peneliti bisa langsung melakukan penelitian yang sudah di rencanakan sebelumnya seperti pada tebel 1 meliputi pengambilan data pada pra dan pasca tes, semua peserta menyelesaikan dua kuesioner: Alat ukur perilaku sosial menggunakan School Social Behavioral Scales (SSBS), Motivasi intrinsik untuk olahraga dan pendidikan jasmani diukur menggunakan Intrinsic Motivation Inventory (IMI). Lalu Peserta menyelesaikan salah satu kondisi pembelajaran modifikasi permainan (SSG) dengan salah satu kelasnya diberi intervensi program motivasi dan perilaku sosial.

\subsection{Instrumen Penelitian}

Untuk menilai instrumen yang baik untuk digunakan, kriteria lain adalah bahwa instrumen berisi prosedur pencatatan yang sesuai dengan data yang peneliti butuhkan untuk menjawab pertanyaan atau hipotesis penelitian. Hasil pengisian instrument berupa data dapat dilaporkan sendiri dengan cara para peserta memberikan informasi, seperti pada tes prestasi atau pada kuesioner sikap. Atau, peneliti dapat mencatat data pada formulir dengan mengamati, mewawancarai, atau mengumpulkan dokumen.

a. Alat ukur perilaku sosial menggunakan School Social Behavioral Scales (SSBS) (Merrell, 2002).

b. Motivasi intrinsik untuk olahraga dan pendidikan jasmani diukur menggunakan Intrinsic Motivation Inventory (IMI) (McAuley et al., 1987).

Angket atau kuesioner adalah sejumlah pertanyaan tertulis digunakan untuk memperoleh informasi dari responden dalam tentang determinasi diri.

\subsection{Analisis Data}

Dalam mengolah dan menganalisis data, peneliti menggunakan analisis data ANOVA, pengolahan data tersebut digunakan mengacu pada penelitian yang telah dilakukan oleh (Pan, 2010) dengan kriteria penerimaan $\alpha=0,05$. Pengolahan data menggunakan ANOVA dilakukan karena data dalam penelitian ini berdistribusi normal dan memiliki variansi data yang homogen, yang sebelumnya sudah di olah menggunakan uji kolmogorov-smirnof untuk uji normalitas dan levine test untuk uji homogenitas data. Pengolahan data dalam penelitian ini dibantu dengan software SPSS v.23 for mac.

\section{HASIL DAN PEMBAHASAN \\ 3.1 Hasil}

Hasil data Intrinsic Motivation Inventory (IMI) dan School Social Behavior Scale (SSBS) pada pretest dan posttest kelompok eksperimen dan kelompok control. Hasil tersebut akan digunakan untuk menarik kesimpulan penelitian sesuai dengan masalah penelitian, pertanyaan penelitian, hipotesis, dan tujuan penelitian. Untuk dapat menarik kesimpulan dari data yang sudah didapatkan tersebut harus diolah dan dianalisis terlebih dahulu. pengolahan data dilakukan berdasarkan prosedur pengolahan data yang telah dipaparkan di BAB III, yang terdiri dari beberapa bagian, yakni pemaparan data dan pengujian hipotesis. Data didapatkan dalam bagian pemaparan data berupa rata-rata, standar deviasi, dan perolehan pesentase IMI dan SSBS siswa, sedangkan pengujian hipotesis berisis uji prasarat statistis dan uji hipotesis terhadap tiga hipotesis yang telah dirumuskan di BAB III.

Pada pretest kelompok kontrol diperoleh dengan nilai simpangan baku $(\sigma=11,32)$ dan mengalami peningkatan pada saat posttest dengan nilai simpangan baku $(\sigma=14,18)$ dengan rentang skor 2,85 . Pada pretest kelompok eksperimen diperoleh nilai simpangan baku $(\sigma=11,10)$ dan mengalami peningkatan juga pada saat posttest dengan nilai simpangan baku $(\sigma=14,08)$ dengan rentang skor 2,98.

Pada pretest kelompok kontrol diperoleh nilai simpanganbaku $(\sigma=8.65)$ dan mengalami peningkatan pada saat posttest dengan nilai simpangan baku $(\sigma=10.38)$ dengan rentang skor 1,73. Pada pretest kelompok eksperimen diperoleh nilai simpangan baku 
$(\sigma=7.99)$ dan mengalami peningkatan pada saat posttest dengan nilai simpangan baku $(\sigma=11.40)$ dengan rentang skor 3,41.

Untuk mengetahui perbedaan pengembangan intrinsic motivation dan social behaviour siswa melalui penerapan model Small-Side Games dalam pembelajaran maka dilakukan uji anova. Uji Anova dilakukan karena lebih dari dua kelompok.

Pengambilan keputusan berdasarkan pada ketentuan sebagai berikut:

Hipotesis:

a. $H_{0}=$ Tidak terdapat perbedaan pengembangan intrinsic motivation dan social behavior melalui model SmallSide Games.

b. $H_{0}=$ Terdapat perbedaan pengembangan intrinsic motivation dan social behavior melalui model Small-Side Games.

Kriteria keputusan:

a. Terima $H_{0}$ jika nilai (Sig.) $>0,05$

b. Tolak $H_{0}$ jika nilai (Sig.) $<0,05$

Intrinsic Motivation adalah 0,048

$<0,05$ maka $H_{0}$ ditolak. Artinya terdapat perbedaan pengembangan Intrinsic Motivation melalui penerapan model SmallSide Games. Social Behavior adalah 0,039 $<0,05$ maka $H_{0}$ ditolak. Artinya terdapat perbedaan pengembangan Social Behavior melalui penerapan model Small-Side Games. Untuk melihat perbedaan antara dua kelompok mana yang lebih tinggi sig. maka dilakukan uji LSD untuk mengetahuinya.

Tabel 2. Hasil Uji LSD IMI

\begin{tabular}{|c|c|c|c|c|c|c|c|}
\hline \multicolumn{8}{|c|}{ Descriptives } \\
\hline & & \multirow{2}{*}{$N$} & \multirow{2}{*}{ Mean } & \multirow{2}{*}{$\begin{array}{c}\text { Std. } \\
\text { Deviation }\end{array}$} & \multirow{2}{*}{ Sig. } & \multicolumn{2}{|c|}{ 95\% Confidence Interval for Mean } \\
\hline & & & & & & Lower Bound & Upper Bound \\
\hline \multirow{3}{*}{ IMI } & Kontrol & 20 & 15.25 & 11.489 & - & 9.87 & 20.63 \\
\hline & Eksperimen & 20 & 15.90 & 6.456 & - & 12.88 & 18.92 \\
\hline & Total & 40 & 15.58 & 9.204 & .048 & 12.63 & 18.52 \\
\hline
\end{tabular}

Berdasarkan tabel 2 nilai sig. Intrinsic Motivation adalah $0,048<0,05$ maka $H_{0}$ ditolak. Artinya terdapat perbedaan skor pengembangan Intrinsic Motivation melalui penerapan model Small-Side Games. Membandingkan nilai Intrinsic Motivation kelompok eksperimen dengan nilai mean 15,90. dan kelompok kontrol dengan nilai mean 15,25. Hal itu berarti nilai Intrisic Motivation pada kelompok eksperimen lebih tinggi dibandingkan dengan kelompok kontrol.

Tabel 3. Hasil Uji LSD SSBS

\begin{tabular}{|c|c|c|c|c|c|c|c|}
\hline \multicolumn{8}{|c|}{ Descriptives } \\
\hline & & \multirow{2}{*}{$N$} & \multirow{2}{*}{ Mean } & \multirow{2}{*}{$\begin{array}{c}\text { Std. } \\
\text { Deviation }\end{array}$} & \multirow{2}{*}{ Sig. } & \multicolumn{2}{|c|}{ 95\% Confidence Interval for Mean } \\
\hline & & & & & & Lower Bound & Upper Bound \\
\hline \multirow{3}{*}{ SSBS } & Kontrol & 20 & 10.65 & 9.670 & - & 6.12 & 15.18 \\
\hline & Eksperimen & 20 & 11.95 & 9.423 & - & 7.54 & 16.36 \\
\hline & Total & 40 & 11.30 & 9.447 & .039 & 8.28 & 14.32 \\
\hline
\end{tabular}

Berdasarkan tabel 3 nilai sig. Social Behavior adalah 0,669 $<0,05$ maka $H_{0}$ ditolak. Artinya terdapat perbedaan skor pengembangan Social Behavior melalui penerapan model Small-Side Games. membandingkan nilai Social Behavior kelompok eksperimen dengan nilai mean 11,95. dan kelompok kontrol dengan nilai mean 10,65. Hal itu berarti nilai Social Behavior pada kelompok eksperimen lebih tinggi dibandingkan dengan kelompok kontrol. 


\subsection{Pembahasan}

Berdasarkan materi yang telah dijelaskan sebelumnya, penelitian ini membahas mengenai terdapat atau tidaknya pengaruh dari adanya pemberian perlakuan menerapkannya model Small-Side Games terhadap motivasi intrinsik dan perilaku sosial siswa. Penelitian ini dilakukan pada siswa Sekolah Menengah Pertama (SMP), dengan rentang usia 12-15 tahun sesuai dengan kategori atau pun masalah yang terjadi disetiap proses pembelajaran berlangsung.

Pada penelitian ini, dibagi menjadi dua kelompok penelitian yaitu kelompok eksperimen (kelompok yang diberi treatment Small-Side Games dengan intervensi IMI dan SSBS) dan kelompok kontrol (kelompok yang diberi treatment Small-Side Games dengan tidak diberi intervensi IMI dan SSBS). Hasil temuan data penelitian menunjukan bahwa kelompok eksperimen lebih unggul dalam pengembangan motivasi intrinsic nya daripada kelompok kontrol. Hal tersebut dibuktikan dengan perhitungan Anova dan t-hitung pada masing-masing kelompok. Dimana kelompok eksperimen lebih unggul dalam mengembangkan atau meningkatkan motivasi intrinsic daripada kelompok kontrol. Berdasarkan hasil tersebut, dapat kita simpulkan bahwa meskipun antara kelompok eksperimen dan kelompok kontrol terlihat memiliki persamaan dengan diterapkannya model Small-Side Games kepada kedua kelompok, namun ada perbedaan yang signifikan ketika di kelompok eksperimen lebih diberi intervensi ataupun wawasan mengenai motivasi intrinsik dapat juga mempengaruhi perubahan yang signifikan dari kedua kelompok tersebut.

Di seluruh studi yang dilakukan, dapat disimpulkan bahwa dengan mengubah faktor-faktor seperti sejumlah pemain, ukuran nada, ada / tidaknya penjaga gawang dan gol, dorongan pelatih dan aturan, pelatih dapat memanipulasi efek SSG pada pemain. Namun, karena kurangnya konsistensi dalam desain SSG, kebugaran pemain, usia, kemampuan, tingkat dorongan pelatih atau guru, dan aturan bermain di antara studi, sulit untuk membuat kesimpulan yang akurat tentang pengaruh masing-masing faktor secara terpisah. Karena keterbatasan ini, manajemen SSG memerlukan penyelidikan lebih lanjut. Penggunaan kondisi standar dalam studi SSG mungkin akan memungkinkan pemahaman yang lebih baik tentang peran faktor individu dan dapat membantu peneliti untuk menemukan kesimpulan yang lebih baik.

Di SSG para pemain mengalami situasi serupa yang mereka temui dalam pertandingan kompetitif (Owen et al., 2004). Karena fakta ini, pengkondisian berbasis game menggunakan SSG telah menjadi metode populer untuk mengembangkan kebugaran aerobik spesifik untuk pemain sepak bola (Impellizzeri et al., 2006). Meskipun semakin populernya SSG, tidak banyak proyek penelitian yang meneliti bagaimana intensitas SSG dapat dimanipulasi untuk mengubah stimulus pelatihan (HillHaas et al., 2009). Penelitian difokuskan pada evaluasi respons fisiologis, taktis, dan teknis atlet ketika faktor-faktor seperti sejumlah pemain, ukuran lapangan, aturan permainan, dan dorongan pelatih telah dimodifikasi dalam SSG. Studi-studi tampaknya mengkonfirmasi bahwa dengan mengubah faktor-faktor ini kita dapat memanipulasi keseluruhan beban kerja fisiologis dan persepsi.

Selain melihat motivasi intrinsik, dalam penelitian ini juga sekaligus memperhatikan ada tidaknya pengaruh dari model SmallSide games yang diberikan terhadap social behaviour untuk kedua kelompok penelitian yaitu kelompok eksperimen (kelompok yang diberi treatment Small-Side Games dengan intervensi IMI dan SSBS) dan kelompok kontrol (kelompok yang diberi treatment Small-Side Games dengan tidak diberi intervensi IMI dan SSBS). Hal tersebut dibuktikan juga dengan perhitungan Anova dan t-hitung pada masing-masing kelompok. Dimana kelompok eksperimen lebih unggul dalam mengembangkan atau meningkatkan perilaku sosial daripada kelompok kontrol. Berdasarkan hasil tersebut juga, dapat kita simpulkan bahwa meskipun antara kelompok eksperimen dan kelompok kontrol terlihat memiliki persamaan dengan diterapkannya 
model Small-Side Games kepada kedua kelompok, namun ada perbedaan yang signifikan ketika di kelompok eksperimen lebih diberi intervensi ataupun wawasan mengenai perilaku sosail nya juga yang dapat mempengaruhi perubahan yang signifikan dari kedua kelompok tersebut.

Modifikasi dalam jumlah sentuhan bola per orang secara berbeda mempengaruhi aktivitas pemain dari babak pertama hingga terakhir, yang menunjukkan bahwa penentuan aturan ini harus direncanakan dengan tepat oleh pelatih atau guru yang sesuai dengan tujuan pelatihan. Pelatih harus menentukan komponen mana (teknis dan / atau fisik) yang ingin mereka sukai, dan, oleh karena itu, mereka harus menentukan jumlah kontak bola yang diizinkan. Akhirnya, tampak bahwa 3 vs 3 yang dimainkan dalam bentuk SSG adalah yang terbaik untuk mengumpulkan tindakan intensitas tinggi secara bersamaan dan untuk menghadapi para pemain dengan situasi teknis yang mirip dengan yang ditemukan selama pertandingan berlangsung. Berdasarkan temuan yang sudah ada, diharapkan bahwa pemahaman tentang beban pelatihan atau pengajaran akan ditingkatkan, memberikan kepada pelatih atau guru informasi yang berharga untuk penggunaan pelatihan SSG.

SSG memungkinkan siswa berkembang dilingkunganyang sangat positif, seperti keterampilan teknis, taktis, sosial dan mental mereka pengambilan keputusan (Owen et al., 2004). Akibatnya, dibenarkan penggunaan SSG dalam perencanaan kelas pendidikan jasmani, karena mencakup persyaratan fisik yang mirip dengan yang ditemukan dalam permainan dan berfokus pada pembelajaran melalui permainan. Selain itu, jenis pengajaran yang difokuskan dalam permainan ini memberikan tingkat motivasi dan keterlibatan siswa yang tinggi dalam tugas. Manipulasi kendala yang digunakan dalam penelitian ini tidak mempengaruhi indikator kinerja teknis dan taktis dalam bola basket dan futsal. Dengan demikian, dimungkinkan untuk menggunakan antara 6 dan 9 pemain tanpa secara signifikan mengubah tindakan teknis dan taktis selama pertandingan. Indikator taktis handball telah secara signifikan dipengaruhi oleh manipulasi variabel, khususnya jumlah pemain. Menambahkan pemain berkontribusi pada durasi yang lebih tinggi dari fase ofensif yang gagal, jumlah operan per fase, operan yang sukses per fase ofensif dan untuk mengurangi penguasaan bola per pemain. Indikator fisiologis dalam semua olahraga tim menunjukkan bahwa penurunan jumlah pemain dan target berkontribusi pada nilai rata-rata yang lebih tinggi dan waktu yang dihabiskan di zona permainan yang ditentukan. Sebagai stimulus fisiologis yang lebih tinggi ditemukan dalam situasi SSG $3 \times 3$ untuk semua olahraga tim, namun, nilai yang lebih tinggi ditemukan di $3 \times 3$. Dengan hanya menggunakan satu target, permainan cenderung lebih fokus dalam kegiatan tertentu, memungkinkan pemain untuk bertindak lebih ke dalam permainan, dan dapat meningkatkan intensitas permainan.

\section{KESIMPULAN}

Proses pembelajaran di sekolah sangat penting ketika dalam prosesnya terdapat makna yang dapat merubah siswa menjadi lebih baik. Dengan penerapan proses pembelajaran yang dibuat menarik dan mengandung makna dalam proses pembelajarannya sudah pasti akan dapat membentuk karakter siswa menjadi lebih baik kedepannya. Dalam proses latihan atau pembelajaran terdapat beberapa metode dan model untuk mencapai keberhasilan, salah satunya yaitu model latihan SmallSided Games. Penelitian ini mengungkapkan betapa pentingnya proses pembelajaran yang dibuat dengan sangat menarik dan mudah dilakukan oleh siswanya, dalam hal ini peneliti menerapkan model latihan Small-Side Games, hal ini dikarenakan adanya pengaruh ketika proses pembelajaran dibuat menarik dan lebih memiliki nilai dalam setiap kegiatan yang dilakukan siswa terhadap motivasi intrinsik dan perilaku sosial setelah melalui proses pembelajaran dengan menggunakan model latihan SmallSide Games. Sesuai dengan hasil penelitian, dapat diambil kesimpulan bahwa; pertama, 
terdapat pengaruh dari penerapan model latihan Small-Side Games terhadap motivasi intrinsik siswa. Kedua, terdapat pengaruh Small-Side Games terhadap perilaku sosial siswa. Ketiga, terdapat perbedaan antara kelompok yang diberikan model latihan Small-Side Games dengan kelompok pembelajaran konvensional motivasi intrinsik dan perilaku sosial.

Temuan penelitian seperti dipaparkan diatas berimplikasi terhadap beberapa hal. Dari perspektif teoritis, rumpun keilmuan perilaku kognitif khususnya teori perilaku dapat digunakan untuk memprediksi penelitian yang dilakukan. Pengetahuan kebugaran terkait kesehatan, yang berlandaskan pada teori perilaku berencana, merupakan pengetahuan yang penting untuk membentuk sikap dan pada gilirannya sikap memperngaruhi kesiapan untuk berbuat. Karena intervensi untuk model atau metode pembelajaran efektif melalui peningkatan motivasi maupun perilaku sosial siswa dan berkontribusi positif. Menyertai pengembangan perilaku maupun motivasi dalam proses pembelajaran pada umumnya membuka perspektif baru dalam konteks pembinaan yang akan membuat siswa tidak merasa tertekan ketika melakukan kegiatan pembelajaran olahraga, melainkan tertarik untuk bergabung mengikuti proses pembelajaran. Salah satu motif keterlibatan seseorang dalam mengikuti proses pembelajaran olahraga yang berlangsung adalah motivasi intrinsik siswa itu sendiri.

\section{DAFTAR RUJUKAN}

Arau' jo, D. (2013). The study of decision-making behavior in sport. RICYDE: Revista Internacional de Ciencias Del Deporte, 9(31), 1-4. doi:10.5232/ricyde2013.031

Bandura, A. (1977). Self-efficacy: Toward a Unifying Theory of Behavioral Change. Psychological Inquiry, 84(2), 191-215. https://doi.org/10.1037//0033-295X.84.2.191

Bandura, A. (1999). Social Cognitive Theory of Personality. Handbook of Personality: Theory and Research, 154-196. https://doi.org/10.1016/0749-5978(91)90022-L

Biddle, S. J. H., Gorely, T., \& Stensel, D. J. (2004). Health-enhancing physical activity and sedentary behaviour in children and adolescents. Journal of Sports Sciences, 22(8), 679-701. https://doi.org/10.1080/026404 10410001712412

Blanchard, C. M., Kupperman, J., Sparling, P., Nehl, E., Rhodes, R. E., Courneya, K. S., ... Hunt, T. (2007). Ethnicity as a moderator of the theory of planned behavior and physical activity in college students. Research Quarterly for Exercise and Sport, 78(5), 531-541 https://doi.org/10.1080/02701367.2007.105 99452

Boiché, J., Sarrazin, P., Grouzet, F., Pelletier, L., Chanal, J., Boiché, J., \& Motiva-, J. C. S. (2009). Students , Motivational Profiles and Achievement Outcomes in Physical Education: A Self-Determination Perspective. HAL Id: hal-00389858

Cairney, J., Kwan, M. Y., Velduizen, S., Hay, J., Bray, S. R., \& Faught, B. E. (2012). Gender, perceived competence and the enjoyment of physical education in children: a longitudinal examination. International Journal of Behavioral Nutrition and Physical Activity, 9(1), 26. https://doi.org/10.1186/1479-5868-9-26

Cartledge, G., R. Gardner., \& D. Ford. (2008). Diverse learners and exceptionalities: Culturally responsive teaching in the inclusive classroom. Upper Saddle River, NJ: Pearson

Chen, K. (2006). Social skills intervention for students with emotional/behavioral disorders: A litera- ture review from the American perspective. Educational Research and Reviews, 1(3): 143-9

Cloes, M. (2005). Research on the students ' motivation in physical education. The Art and Science of Teaching in Physical Education and Sport, 197-210

Corbin, C. B. (2002). Physical Activity for Everyone: About Promoting Lifelong Physical Activity. Journal of Teaching in Physical Education, 21, 128-144

Davids, K., Arau'jo, D., Correia, V., \& Vilar, L. (2013). How small-sided and conditioned games enhance acquisition of movement and decision-making skills. Exercise and Sport Sciences Reviews, 41(3), 15461. doi:10.1097/JES.0b013e 318292f3ec

Dellal, A., Jannault, R., Lopez-Segovia., \& M. y Pialoux, V. (2011). Influence of the numbers of players in the heart rate responses of youth soccer players within 2 vs. 2, 3 vs. 3 and 4 vs. 4 small-sided games. Journal 
of Human Kinetics, 28, 107-114

Goudas, M., Biddle, S., \& Fox, K. (1994). Perceived locus of causality, goal orientations, and perceived competence in school physical education classes. British Journal of Educational Psychology, 64(3), 453-463. https:// doi.org/10.1111/j.2044-8279.1994.tb01116.x

Greco, P., Memmert, D., \& Morales, J. C. P. (2010). The effect of deliberate play on tac- tical performance in basketball. Perceptual and Motor Skills, 110(3), 849-856. doi:10.2466/PMS.110.3.849-856

Gunarsa S. D. (2008). Psikologi Perkembangan Anak Remaja. Jakarta: PT BPK Gunung Mulia

Hagger, M. S., Barkoukis, V., Chatzisarantis, N. L. D., John Wang, C. K., \& Baranowski, J. (2005). Perceived autonomy support in physical education and leisure-time physical activity: A cross-cultural evaluation of the trans-contextual model. Journal of Educational Psychology, 97(3), 376-390. https://doi. org/10.1037/0022-0663.97.3.376

Hassandra, M., Goudas, M., \& Chroni, S. (2003). Examining factors associated with intrinsic motivation in physical education: A qualitative approach. Psychology of Sport and Exercise, 4(3), 211-223. https://doi. org/10.1016/S1469-0292(02)00006-7

Hill-Haas, S., Dawson, B., Impellizzeri, F. M., \& Coutts, A. J. (2011). Physiology of small-sided games training in football: a systematic review. Sports Med, 41(3):199-220 doi:10.2165/11539740-000000000-00000

Hill-Haas, S., Coutts, A. J., Rowsell, G. J., \& Dawson, B. T. (2009). Generic versus small-sided game training in soccer. International Journal of Sports Medicine, 30(9), 636-642

Hoffmann, J. J., Reed, J. P., Leiting, K., Chiang, C. Y., \& Stone, M. H. (2014). Repeated sprints, high-intensity interval training, small-sided games: Theory and application to field sports. International Journal of Sports Physiology and Performance, 9(2), 352-357. doi:10.1123/IJSPP.2013-0189

Impellizzeri, F. M., Marcora, S. M., Castagna, C., Reilly, T., Sassi, A., Iaia, F. M. (2006). Physiological and performance effects of generic versus specific aerobic training in soccer players. International Journal of Sports Medicine, 27(6), 483-492

Kaltiala-Heino, R., Rimpela, M., Rantanen, P., \& Rimpela, A. (2000). Bullying at school—an indicator of adolescents at risk for mental disorders. Journal of Adolescence, 23, 661 - 674. doi:10.1006/ jado.2000.0351

Koklu, Y., Asci. A., Kocak, F. U., Alemdaroglu, U., \& Dundar, U. (2011). Comparison of the physiological responses to differ- ent small-sided games in elite young soccer players. J Strength Cond Res. 25(6):15221528. doi:10.1519/ JSC.0b013e3181e06ee1

Kolovelonis, A., \& Goudas, M. (2013). The development of self-regulated learning of motor and sport skills in physical education: A review. Hellenic Journal of Psychology, 10(3), 193-210

Lirgg, C. D. (1991). Gender Differences In Self-Confidence in Physical Activity: A Meta-Analysis of Recent Studies. Journal of Sport and Exercise Psychology, 13(3), 294-310. https://doi.org/10.1123/jsep.13.3.294

Malone, T. W., \& Lepper, M. R. (1987). Making learning fun: A taxonomy of intrinsic motivations for learning. In R. E. Snow \& M. J. Farr (Eds.), Aptitude, learning, and instruction: 222. Conative and affective process analyses (pp. 223-253). Hillsdale, NJ: Lawrence Erlbaum Associates, Inc

McAuley, E., Duncan, T., \& Tammen, V. V. (1987). Psychometric properties of the Intrinsic Motivation Inventory in a competitive sport setting: A confirmatory factor analysis. Research Quarterly for Exercise and Sport, 60, 48-58

Memmert, D., \& Roth, K. (2007). The effects of non-specific and specific concepts on tactical creativity in team ball sports. Journal of Sports Sciences, 25(12), 1423-1432

Memmert, D. (2010). Game test situations: Assessment of game creativity in ecological valid situations. International Journal of Sport Psychology, 41, 94-95

Merrell, K. W. (2002). Preschool and Kindergarten Behavior Scales(PKBS-2)examiner's manual (2nd ed.).Te xas: Pro.ed

Moore, R.J., G. Cartledge., \& K. Heckman. (1995). The effects of social skill instruction and self- monitoring on game-related behaviors of adolescents with emotional disorders. Behavioral Disorders, 20: 253-66.

Motl, R. W. (2007). Chapter 2 : Theoretical Models for Understanding Physical Activity Behavior Among Children and Adolescents - Social Cognitive Theory and Self-Determination Theory. Journal of Teaching in Physical Education, 26, 350-357. https://doi.org/10.1123/jtpe.26.4.350

Nansel, T. R., Overpeck, M., Pilla, R. S., Ruan, W. J., Simons-Morton, B., \& Scheidt, P. (2001). Bullying behaviors among US youth: Prevalence and association with psychosocial adjustment. Journal of the American Medical Association, 285, 2094-2100. doi:10.1001/jama.285.16.2094 
National Association for Sport and Physical Education (2004). National standards for physical education (2nd ed.). Reston, VA: Author

Ntoumanis, N. (2004). Dimensions of Coaching Behavior, Need Satisfaction, and the Psychological and Physical Welfare of Young Athletes. European Science Editing, 38(2), 35-37. https://doi.org/10.1023/B

Ntoumanis, N., \& Standage, M. (2009). Morality in Sport: A Self-Determination Theory Perspective. Journal of Applied Social Psychology, 21(4), 365-380.

Ormrod, J. E. (1999). Human Learning, 3rd ed. Upper Saddle River, NJ: Prentice-Hall

Orpinas, P., \& Horne, A. M. (2006). Bully prevention: Creating a positive school climate and developing social competence. Washington, DC: American Psychological Association

Ortega, E., Alarcón, F., \& Piñar, M. (2012). Modificaciones reglamentares en baloncesto de formacion: Un nuevo equipamento, una nueva perspectiva.

Owen, A., Twist, C., \& Ford, P. (2004). Small-sided games: The physiological and technical effect of altering pitch size and player numbers. Insight: The F. A. Coaches Association Journal, 7(2), 50-53

Pan, C. Y. (2010). Effects of water exercise swimming program on aquatic skills and social behaviors in children with autism spectrum disorders. Autism, 14(1), 9-28. https://doi.org/10.1177/1362361309339496

Reilly, T. (2005). An ergonomics model of the soccer training process. Journal of Sports Sciences, 23(6), 561-572

Ryan, R., \& Deci, E. (2000). Self-determination theory and the facilitation of intrinsic motivation, social development, and well-being. The American Psychologist, 55(1), 68-78. https://doi.org/10.1037/0003066X.55.1.68

Sallis, J. F., Prochaska, J. J., \& Taylor, W. C. (2000). A review of correlates of physical activity. Medicine \& Science in Sports \& Exercise, 32(5), 963-975. https://doi.org/10.1097/00005768-200005000-00014

Thornburgh, N. (2006). Special Report - Dropout Nation, 1-9

Travassos, B., Araujo, D., Davids, K., Vilar, L., Esteves, P., \& Vanda, C. (2012). Informational constraints shape emergent functional behaviours during performance of interceptive actions in team sports. Psychology of Sport and Exercise, 13(2), 216-223

Vallerand, R. J., Gauvin, L. I., \& Halliwell, W. R. (1986). Negative Effects of Competition on Children's Intrinsic Motivation. The Journal of Social Psychology,126(5),649-656. https://doi.org/10.1080/00224545.1986. 9713638 